Fussing and Fuming over Fannie and Freddie: How Much Smoke, How Much Fire?

\author{
W. Scott Frame and Lawrence J. White
}

Forthcoming, Journal of Economic Perspectives, 2005

W. Scott Frame is a Financial Economist and Associate Policy Advisor, Federal Reserve Bank of Atlanta, Atlanta, Georgia. Lawrence J. White is the Arthur E. Imperatore Professor of Economics, Stern School of Business, New York University, New York City, New York. Their e-mail

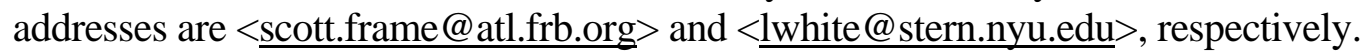

\begin{abstract}
$\underline{\text { Abstract }}$
The roles of Fannie Mae and Freddie Mac have become increasingly controversial in the modern world of residential mortgage finance. We describe the special features of these two companies and their roles in the mortgage markets. We then discuss the controversies that surround them and offer recommendations for improvements in public policy.
\end{abstract}

JEL Classification Numbers: G21, G28

Keywords: Fannie Mae, Freddie Mac, government-sponsored enterprises, residential mortgages, securitization, regulation 
The Federal National Mortgage Association and the Federal Home Loan Mortgage Corporation - commonly known as Fannie Mae and Freddie Mac, respectively ${ }^{1}$-- have led the way in dramatic changes that have taken place in the structure of the U.S. residential mortgage markets since the 1970s. Fannie Mae and Freddie Mac are quasi-private/quasi-public: for example, they have federal charters that confer unique regulatory provisions; but their shares are publicly traded on the New York Stock Exchange. The biggest advantage of Fannie Mae's and Freddie Mac's anomalous legal status arises because financial markets treat their obligations as if those obligations are backed by the federal government - even though the federal government explicitly does not do so. With the benefit of this special status, Fannie Mae and Freddie Mac have grown into enormous financial institutions, with combined total assets of over \$1.8 trillion in 2003. One critic, Richard Carnell (2004), a former Assistant Secretary of the Treasury, has suggested that the two companies’ growth is at least partially a consequence of a "double game” that they play: "[They] tell Congress and the news media, 'Don't worry, the government is not on the hook' - and then turn around and tell Wall Street, 'Don’t worry, the government really is on the hook.'”

The preferential legal status of Fannie Mae and Freddie Mac serves as one of a number of mechanisms by which the federal government encourages the consumption (and, arguably, the overconsumption) of housing in the U.S. economy - this one with an on-budget cost of zero. But economists are congenitally suspicious of programs that seem to offer something for nothing. After all, a federal guarantee of the deposits in savings and loans cost nothing for many decades -- until the early 1990s, when it cost taxpayers about \$150 billion (U.S. Federal Deposit Insurance Corporation, 1997). Furthermore, Federal Reserve Chairman Alan Greenspan (2004), among others,

\footnotetext{
1 The nicknames "Fannie Mae" and "Freddie Mac" originated among securities traders, and the two companies are now far better known by these names than by their formal corporate titles.
} 
has suggested that the anomalous situation of Fannie Mae and Freddie Mac may even pose systemic risks to the financial sector.

This article will offer a generalist's guide to the functions that Fannie Mae and Freddie Mac perform in the residential mortgage financial markets and the controversies that swirl around them. Along the way we will highlight some important -- and perhaps under-appreciated -- changes that are occurring in the structure of U.S. residential mortgage markets.

\section{Some Background}

What Do Fannie Mae and Freddie Mac Do?

Fannie Mae and Freddie Mac participate in the secondary mortgage market: Mortgage originators come to them with pools (bundles) of mortgages and either swap these assets for securities or sell them outright to one of the two companies. Under Fannie Mae's and Freddie Mac’s “swap programs,” an originator exchanges a mortgage pool for a mortgage-backed security that is issued and guaranteed by one of the two companies and that represents an interest in the same pool. Fannie Mae and Freddie Mac promise the security holders that the latter will receive timely payment of interest and principal on the underlying mortgages, less an annual "guarantee fee" of about 20 basis points ( 0.20 percent) on the remaining principal. In essence, Fannie Mae and Freddie Mac are providing insurance to holders of mortgage-backed securities against default risk on the underlying mortgages and are thus bearing that risk themselves. This securitization activity illustrates one of their two core businesses: mortgage credit guarantees.

The other core business of Fannie Mae and Freddie Mac is their investment portfolios. These portfolios consist largely of mortgage-backed securities that they have purchased in the open market, as well as mortgages that they purchase from originators under their "cash programs." 
Fannie Mae and Freddie Mac fund these assets largely by issuing debt, as the two companies are highly leveraged with total equity that is less than 4 percent of total assets.

The major differences between Fannie Mae and Freddie Mac are in their historical roots. The National Housing Act of 1934 created the Federal Housing Authority (FHA) and also provided for chartering national mortgage associations as entities within the federal government. The only association ever formed was the National Mortgage Association of Washington in 1938, which eventually became the Federal National Mortgage Association - now Fannie Mae. By issuing debt and purchasing and holding FHA-insured residential mortgages from “mortgage banks,” Fannie Mae was able to expand the available pool of finance to support housing and also to provide a degree of unification to mortgage markets. During this time, mortgage markets were localized for technological reasons, as well as for reasons rooted in laws that prohibited interstate banking and restricted intra-state bank branches in many states during most of the twentieth century.

In 1968, Fannie Mae was converted into a private corporation, with publicly traded shares listed on the New York Stock Exchange, although it retained a unique federal charter that is discussed further below. Apparently one major reason for the privatization was that until 1968 Fannie Mae's debt was part of the federal debt; but when Fannie Mae became a publicly traded company, that debt (which stayed with the company) was removed from the national debt total. Fannie Mae was replaced within the federal government by the Government National Mortgage Association (which became known as “Ginnie Mae”), an agency within the Department of Housing and Urban Development (HUD) that guarantees mortgage-backed securities that have as their underlying assets residential mortgages that are insured primarily by the FHA or by the Department of Veterans Affairs (formerly the Veterans Administration, or VA).

Freddie Mac, by contrast, was created by Congress in 1970 to support mortgage markets by securitizing mortgages originated by savings and loan associations (S\&Ls). During the 1970s and 1980s, Freddie Mac was technically a private company, with its equity shares held solely by the 
twelve Federal Home Loan Banks (FHLBs) and by S\&Ls that were members of the FHLBs. Freddie Mac's board of directors consisted of the three board members of the Federal Home Loan Bank Board, which regulated the S\&L industry during that time. Freddie Mac was converted in 1989 into a publicly traded company, also traded on the New York Stock Exchange, with the same special features as apply to Fannie Mae. A major motivation for the conversion of Freddie Mac to a publicly traded company was the belief that a wider potential share-holding public would raise the price of the shares held by the then ailing S\&L industry and thus improve the balance sheets of the latter.

In its early history, Freddie Mac tended to securitize mortgages, originated largely by S\&Ls, whereas Fannie Mae tended to hold the mortgages that it bought largely from mortgage banks. By the 1990s, however, the two companies' structures and strategies looked quite similar.

\section{Current Size}

As of year-end 2003, Fannie Mae had \$1,010 billion in assets and Freddie Mac had \$803 billion in assets, making them the second and third largest U.S. companies, respectively, on this basis. In addition, both Fannie Mae and Freddie Mac had significant quantities of mortgage-backed securities outstanding - that is, net of mortgage-backed securities carried on their balance sheets. As of year-end 2003, Fannie Mae had \$1,300 billion in outstanding mortgage-backed securities while Freddie Mac had another $\$ 769$ billion outstanding.

Both Fannie Mae and Freddie Mac have grown rapidly over the past three decades and at a faster clip than the residential mortgage market as a whole. As Table 1 shows, in 1980 the residential mortgage market consisted of $\$ 1.1$ trillion in obligations, of which Fannie Mae and Freddie Mac held or securitized only $\$ 78$ billion, or about 7 percent. By contrast, in 2003, these companies held or securitized over $\$ 3.6$ trillion of the $\$ 7.7$ trillion in residential mortgage debt, or about 47 percent. The U.S. Congressional Budget Office (2001) estimated the involvement of 
Fannie Mae and Freddie Mac in various slices of the mortgage markets as of 2000. For example, for fixed-rate single-family mortgages that were eligible to be purchased or securitized by the two companies (about half of the total residential mortgage market), the two companies accounted for 71 percent of that slice (through either their securitizations or their portfolio holdings).

\section{Special Features of Fannie Mae and Freddie Mac}

Fannie Mae and Freddie Mac differ from other U.S. corporations in that they were created by Congress and maintain exclusive federal charters. These charters, in turn, confer a number of rights and responsibilities on these companies (U.S. Congressional Budget Office, 1996, 2001; U.S. Department of the Treasury, 1996; U.S. Government Accounting Office, 1996).

Some of the advantages that Fannie Mae and Freddie Mac enjoy are as follows. First, they are exempt from state and local income taxes. Second, the Secretary of the Treasury has the authority to purchase up to $\$ 2.25$ billion of Fannie Mae’s and Freddie Mac’s securities. Third, they issue "government securities," as classified under the Securities Exchange Act of 1934, which in practice means that their securities are eligible for use as collateral for public deposits, for purchase by the Federal Reserve in open-market operations, and for unlimited investment by federally insured depository institutions. A further implication is that they are exempt from the registration and reporting requirements and fees of the Securities and Exchange Commission, although Fannie Mae voluntarily registered its stock with the SEC in March 2003, and they are exempt from the provisions of many state investor protection laws. Fourth, they use the Federal Reserve as their fiscal agent, which means that their securities are issued and transferred using the same system as U.S. Treasury borrowings.

Fannie Mae’s and Freddie Mac’s federal charters also present some disadvantages for these companies. First, their activities are restricted to residential mortgage finance. Second, they are restricted to the secondary market, which means that they cannot originate mortgages directly. 
Third, there is a maximum size of mortgage that they can finance. These mortgages are usually described as "conforming" mortgages; larger mortgages are usually described as "jumbos." ${ }^{2}$ The size is linked to an annual index of housing prices; for 2004, the limit for a single-family home is $\$ 333,700$. Fourth, the mortgages that they finance must have at least a 20 percent down payment, or else have mortgage insurance that is provided either by private firms or the federal government. Fifth, they are subject to federal safety-and-soundness regulation, including minimum leverage and risk-based capital requirements and supervisory examinations, by the Office of Federal Housing Enterprise Oversight (OFHEO), an independent agency within the Department of Housing and Urban Development (HUD). Sixth, they are subject to "mission oversight" by HUD, which approves new housing finance programs and sets percent-of-business housing finance goals. Currently, 50 percent of Fannie Mae's and Freddie Mac's business must benefit low- and moderateincome families, 31 percent must benefit underserved areas, and 20 percent must serve "special affordable” needs.

\section{A Halo of Government Support}

By law, securities of Fannie Mae and Freddie Mac are required to include language that they are not guaranteed by, or otherwise an obligation of, the federal government. However, Fannie Mae's and Freddie Mac's special federal charters and the attendant package of special benefits directly lower their operating costs and have created a "halo" of implied federal government support for the two companies. In addition, past government actions have contributed to the perception of implied government support. During the late 1970s and early 1980s, Fannie Mae was insolvent on a market value basis and benefited from supervisory forbearance (U.S. General Accounting Office,

\footnotetext{
${ }^{2}$ Other non-conforming mortgages (besides jumbos) are those that do not meet the credit-quality standards of the two companies. Also, this limit applies only to a single-unit residence; higher limits apply to two-unit, three-unit, and fourunit residences and to multi-family housing. Also, limits for Hawaii, Alaska, and the Virgin Islands are, by law, 50 percent higher.
} 
1990; Kane and Foster, 1986). A summarizing phrase for this halo is that the two companies are “government sponsored enterprises” (GSEs). ${ }^{3}$

Evidence suggests that financial markets believe that the federal government would come to the rescue of Fannie Mae and Freddie Mac (and hence their creditors) in the event of financial difficulties. As a result of this perceived implicit guarantee, Fannie Mae and Freddie Mac can typically borrow at interest rates that are more favorable than those of a AAA-rated corporation (though not quite as favorably as the rates on government debt), even though their stand-alone ratings would be about AA- or less. For Fannie Mae and Freddie Mac, empirical studies suggest that this translates into roughly a 35-40 basis point debt funding advantage, although there is significant variation in the estimates depending on the credit rating and maturity of the comparison bonds (Ambrose and Warga, 1996, 2002; Nothaft, Pearce and Stevanovic, 2002). Other studies have found that the companies enjoy about a 30 basis point advantage in issuing mortgage-backed securities (U.S. Congressional Budget Office 1996, 2001; U.S. Department of the Treasury, 1996).

The presence of Fannie Mae and Freddie Mac in the secondary mortgage market influences the primary mortgage market. Most notably, Fannie Mae's and Freddie Mac's activities result in “conforming” mortgages’ carrying lower interest rates than jumbo mortgages. Several econometric studies have estimated this effect, and most found the interest rate differential to be about 20-25 basis points, although the estimates vary depending on the empirical specification, data sample, and time period studied. For an introduction to this literature, see U.S. Congressional Budget Office (2001), McKenzie (2002), Passmore (2003), and Ambrose, LaCour-Little and Sanders (forthcoming), and the references in these papers.

\footnotetext{
${ }^{3}$ The Federal Home Loan Bank System, which serves as a wholesale bank for many federally insured depository institutions (banks, S\&Ls, and credit unions), enjoys a similar package of favorable features and is similarly described as a GSE. There are also GSEs that serve agricultural credit markets (Farm Credit System and the Federal Agricultural Mortgage Corporation, or Farmer Mac) and the student loan market (Student Loan Marketing Association, or Sallie Mae), although the latter is in the process of privatization under the name SLM Corp. The financial pages of major newspapers often set aside a separate box of "agency issues" to report the yields on GSE securities - a visible illustration of how they are treated differently.
} 
Fannie Mae and Freddie Mac may bring other potential benefits to mortgage markets, although these claims are often controversial. For example, one controversy is over whether Fannie Mae and Freddie Mac enhance the stability of the mortgage market by acting as a large "market maker” in mortgage-backed securities and thereby reducing interest rate volatility in that market (Gonzalez-Rivera, 2001; Naranjo and Toevs, 2002; Peek and Wilcox, 2003). We will discuss one counterargument to this point below - the possibility that the sheer size of these mortgage portfolios creates a potential for systemic risk in the financial system.

Another claim sometimes made is that Fannie Mae and Freddie Mac can act as a focal point for market-wide standard setting with respect to technology and certain "best practices.” For example, Fannie Mae and Freddie Mac have each developed widely used automated underwriting systems (known as Desktop Underwriter and Loan Prospector, respectively) that evaluate an individual loan's credit risk, including whether it meets the companies' purchase requirements. These systems have greatly reduced the time and cost of the mortgage origination process. However, several large lenders that already had similar systems in place resented the Fannie Mae and Freddie Mac systems, characterizing them as an unwarranted intrusion into the primary mortgage market.

\section{Residential Mortgages: A Primer}

To appreciate the central role that Fannie Mae and Freddie Mac play in U.S. residential mortgage finance, a brief tutorial on mortgage finance itself will be useful, including the process of mortgage securitization.

\section{Some Interesting Aspects of Residential Mortgages}


At one level, a residential mortgage is a simple debt instrument. The purchaser of a home borrows money to finance the home purchase. The home serves as the collateral for the loan. The borrower makes monthly payments that cover the interest on the outstanding principal and the amortization of that principal.

The complexity of the mortgage as a debt instrument arises because of the interactions among three properties of most U.S. single-family residential mortgages: lengthy maturities, fixed interest rates, and "free" prepayment options. ${ }^{4} \quad$ First, the term of most mortgages is for 15 or 30 years, with the average term of a new mortgage for a single-family residence hovering at about 2728 years over the past decade. Second, fixed-rate mortgages are more common than adjustable-rate mortgages, which have been one-quarter or less of the market in the last 6-7 years and exceeded one-third of the market in only a single year during the 1990s. Indeed, adjustable rate mortgages were relatively unknown before the early 1980s, primarily because federal regulation prevented most depository institutions from originating them. Finally, these long-term, fixed-rate mortgages are generally prepayable without a penalty, in the sense that the borrower can accelerate the repayment of principal or repay the entire amount at any time, at no additional cost. Though the borrower does not pay an explicit penalty at the time of repayment, the cost of the option to the lender is incorporated into the contract interest rate and the fees that the lender charges at the time of origination.

A mortgage lender faces two kinds of risks. First, credit risk bears on whether the lender will be repaid the principal amount that has been lent and the contracted interest. Second, market risk refers to whether changes in market conditions -- primarily interest rate changes - will affect the value of the mortgage.

\footnotetext{
${ }^{4}$ More detail on the characteristics of residential mortgages can be found on the website of the Federal Housing Finance Board: <http://www.fhfb.gov> .
} 
The credit risk on most single-family residential mortgages is quite low. ${ }^{5}$ After all, lenders only originate such loans after screening for adequate household income and a good credit history. Further, the home itself serves as the collateral for the mortgage in the event of default. Most lenders require a 20 percent down payment or some form of mortgage insurance. The credit risk losses on mortgages held by Fannie Mae and Freddie Mac averaged 5.4 basis points annually over the 19872002 period, and the losses averaged only 1 basis point annually for 1999-2002 (Inside Mortgage Finance, 2003).

A fixed-rate debt instrument also creates market risk for the lender. If interest rates increase, the price of the instrument declines; and if interest rates decrease, the price of the instrument rises. The longer is the maturity of the instrument, the greater are the associated price swings. These risks are further complicated by changes in the rate of prepayment. A lower interest rate, which would benefit the lender of a fixed-rate instrument, makes borrowers more likely to repay their existing mortgages, either by refinancing the existing mortgage or deciding that the time is right to purchase a new home. This quickening of the repayment rate deprives the lender of the potential capital gain on the mortgage that would otherwise occur on a debt instrument that could not be repaid; equivalently, the greater pace of repayment is occurring just when the lender doesn't want repayment, since the lender can then only relend (or reinvest) the funds at the lower prevailing interest rates. Conversely, a higher interest rate leads to less prepayment. In this case, the capital loss that the lender would have experienced on a fixed-rate debt instrument as interest rates increase is compounded by the slackening of the prepayment rate; in essence, prepayments are slackening just when the lender wishes that they would

\footnotetext{
${ }^{5}$ Two growth areas in residential mortgage lending that are exceptions to this broad claim are "subprime" and high loan-to-value loans. Subprime loans are those made to borrowers with material blemishes in their recent credit history. High loan-to-value loans, while generally made to individuals with especially good credit, have principal amounts equal to or greater than the appraised value of the property acting as collateral.
} 
accelerate. In the specialized literature, this phenomenon of additional adverse effects on the mortgage lender from decreases or increases in interest rates is described as the "negative convexity" of the mortgage instrument.

\section{Mortgage Securitization}

Prior to 1970 , mortgages were largely a non-traded debt instrument. ${ }^{6}$ The initial lender that originated the loan usually held the loan until it matured (or was prepayed), collecting interest and principal repayments in the interim. In 1970, Ginnie Mae issued the first "pass-through" mortgagebacked securities, which created a claim on an underlying pool of residential mortgages and meant that security-holders had the right to receive a fractional share of the interest and principal repayments of the pool as a whole. The Ginnie Mae securities carried the federal government's promise of timely payment of interest and principal, on top of the guarantees issued by the FHA and the VA on the underlying mortgages. For the first time, the claim on a stream of mortgage payments could be readily traded.

A number of aspects of mortgage-backed securities are worth noting. First, securitization greatly widens the potential market for the ultimate financing of residential mortgages. Anyone who buys the security directly or indirectly (for example, through a mutual fund or pension fund) is, in essence, providing the mortgage financing.

Second, investors in mortgage-backed securities are in a poor position to assess the credit risk as to what proportion of the individual mortgages in the underlying pool will be repaid on schedule, so they require some assurance on these credit risks. Ginnie Mae, Fannie Mae, and Freddie Mac offer direct guarantees with respect to these repayment rates when they issue such securities. "Private-label” securitizations offer other kinds of reassurance: for example, private

\footnotetext{
${ }^{6}$ As was mentioned above, an exception to this pattern involved originations by mortgage banks, which immediately sold the mortgages to Fannie Mae (which then held the mortgages in its portfolio).
} 
financial guarantees; “overcollateralization,” in which a security issuer pledges assets to back the securitization in an amount that exceeds the face value of the securities being issued; or structuring the securities with senior and subordinated tranches, such that credit losses are first absorbed by more subordinate securities up to certain values.

Third, mortgage-backed securities holders are not protected from the market risks associated with holding long-term, fixed-rate, prepayable mortgages. The holder of a simple "pass-through" mortgage-backed security (described above) experiences the same effects of interest rate changes -- including the effects of prepayments -- as does the owner of an otherwise similar unsecuritized pool of mortgages.

Fourth, the securitization process creates opportunities for "slicing and dicing" the cash flows in ways that allow the risks to be better allocated among capital markets participants according to their preferences (Fabozzi, 2001). The "senior/subordinated" structure noted above is one such method. As another example, the cash flows from a mortgage pool can be divided into a "principal-only" security and an "interest-only" security, where the former has characteristics that heighten interest-rate risks, while the latter (at least for modest changes in interest rates) ameliorates them. ${ }^{7}$ More elaborate multiple-layer securities, in which some investors have more buffering from early prepayment and others have less, can also be created from Fannie Mae or Freddie Mac pass-through securities and are described as "collateralized mortgage obligations" (CMOs) or "real estate mortgage investment conduits" (REMICs).

\footnotetext{
${ }^{7}$ These characteristics are most readily seen by first considering the properties of the interest-only security: Holders receive payments only so long as the borrower does not prepay the mortgage (at which time the holder ceases receiving anything). Thus, when interest rates rise and prepayments slacken, the effect of the lengthening of the expected stream of interest payments may exceed the effect of the higher discount rates that should be applied to those payments, and the value of the interest-only instrument may rise. Since the value of the overall mortgage falls when interest rates rise, the value of the principal-only instrument must fall by an even greater percentage. Conversely, when interest rates fall, the value of the interest-only instrument could fall as well (the effect of the shortening of the expected stream of interest payments could exceed the effect of the lower discount rates), while the value of the principal-only instrument rises in value (because of both the lower discount rate and the quicker repayment of principal).
} 


\section{Trends in Residential Mortgage Finance}

The structure of residential mortgage markets is substantially different today than it was in 1970. At that time, the dominant pattern was as follows: The financial institution -- typically a savings and loan or a savings bank -- that originated a fixed-rate mortgage loan also held it in its portfolio, and the same financial institution collected the monthly payments and dealt with delinquencies. The funding for the loan was provided by the institution's deposits, which were insured by the federal government, through the Federal Savings and Loan Insurance Corporation (for S\&Ls) or the Federal Deposit Insurance Corporation (for commercial banks). As Table 2 shows, in 1970 savings and loan institutions held over 56 percent of outstanding single-family mortgages, and commercial banks and savings and loans together held over 70 percent.

By contrast, the typical pattern today is for mortgage originators to share some or all of the risks associated with fixed-rate residential mortgage loans with the secondary market. Depository institutions typically do this by securitizing their conforming mortgages with Fannie Mae or Freddie Mac and their FHA- and VA- insured loans with Ginnie Mae. The resulting mortgage-backed securities carry an assurance as to the timely payment of principal and interest, which is backed by a full-faith-and-credit guarantee of the federal government (Ginnie Mae) or an implied federal guarantee (Fannie Mae and Freddie Mac). The originator will elect either to hold or to sell the mortgage-backed security, although it may continue to "service" the underlying loans by collecting monthly payments and dealing with delinquencies. Non-depository mortgage originators, such as mortgage banks, tend to sell their mortgages outright - often to Fannie Mae or Freddie Mac.

Only adjustable rate mortgages or those fixed-rate mortgages that exceed the conforming loan limits ("jumbos") or that do not meet certain the underwriting criteria are likely to be held in the originator's portfolio (if the originator is a depository institution) or securitized in a "private label" offering. As Table 2 also shows, as of year-end 2000, the share of "whole loan" singlefamily mortgages held by banks and savings and loans had plummeted to below 30 percent, despite 
an increase in commercial banks' share of single-family mortgage mortgages between 1970-2000. However, if one were also to include the banks’ and S\&Ls’ holdings of mortgage-backed securities (and thus the depositories' exposure to mortgage-related market risk), their share would rise to slightly over 40 percent.

This vertically dis-integrated structure allows for greater specialization among institutions with respect to mortgage originations, collecting payments, dealing with delinquent loans, funding, liability issuance, and guarantees.

\section{Why the Trend to Securitization and Dis-Integration of Mortgage Markets?}

Technological advancements -- especially improved and lower-cost data processing and telecommunications - have undergirded both the expansion of the securitization process and division of the market into many interlocking providers. Loan originators are able to gather information about prospective borrowers, analyze it, make judgments about who to lend to, and transmit that information and those judgments to others - notably, securitizers and investors -- in ways and over distances that weren't possible in the 1970s. Regulation, however, has also contributed to the expanded role of Fannie Mae and Freddie Mac in residential mortgage markets, in at least two ways. First, since 1988, the regulatory risk-based capital (net worth) requirements that apply to banks and savings and loans have included a lower requirement of 1.6 percent for holding mortgage-backed securities issued by Fannie Mae and Freddie Mac, compared with the 4 percent requirement for holding whole (unsecuritized) residential mortgage loans. At first blush, since riskbased capital requirements for whole-loan mortgages are at the same level as the minimum "leverage” requirements for an adequately capitalized depository institution (a 4 percent ratio of a depository’s overall capital to assets), there would seem to be little market impact from these riskbased capital charges. However, in cases where a depository institution holds a diversified loan portfolio that includes higher-risk loans requiring capital levels above the minimum leverage 
requirements, their portfolio may be bound by risk-based capital requirements. So, at the margin, the lower capital requirements for mortgage-backed securities would strongly encourage the institution to substitute mortgage-backed securities for "whole" mortgage loans. Frame and White (2004b) discuss this “regulatory capital arbitrage” in greater detail.

Second, Fannie Mae and Freddie Mac are required to hold at least 2.5 percent capital against mortgages (or their own mortgage-backed securities) that they retain in their portfolios. At first glance, this would seem to put such portfolio retention at a capital cost disadvantage as compared with depositories’ holdings of mortgage-backed securities (at 1.6 percent). But in comparison with depositories that are bound by the 4 percent minimum leverage requirement (such as savings and loans that tend to specialize in mortgage lending), the purchases by Fannie Mae and Freddie Mac for their own portfolios would have a capital cost advantage.

Strategic management decisions have also been an influence. When Freddie Mac became a publicly traded company in 1989 and was freed from the constraints that had previously been imposed by the Federal Home Loan Bank Board, its management soon realized that its favorable borrowing rates provided an excellent opportunity to expand its income by earning a spread on the difference between mortgages that it held in portfolio and its favorable borrowing rates. Though Fannie Mae was chastened and restrained by its near-insolvency in the early 1980s, by the 1990s its management had also adopted this expansionist mentality.

Ironically, Fannie Mae and Freddie Mac did not expand as dramatically in the 1970s and 1980s, when their position as national operators in mortgage markets should have given them a comparative advantage vis-à-vis their depository rivals who were restrained by state and federal limitations on interstate branching. Apparently, it took technological and regulatory changes, supplemented by some strategic management decisions, to bring about their expansion. 


\section{The Issues}

The federal charters for Fannie Mae and Freddie Mac, and particularly the implied federal guaranty of their financial obligations, raise the central policy issue. On one side, the implied guarantee on Fannie Mae’s and Freddie Mac's financial obligations allows the federal government to reduce mortgage interest rates for most residential mortgages by about 20-25 basis points -- without an annual appropriation. On the other side, this policy creates a contingent liability for taxpayers in the event that either enterprise becomes insolvent and the government elects to provide financial assistance, as well as causing additional distortions in the housing market. These tradeoffs involving Fannie Mae and Freddie Mac can then be parsed into five related issues: a) how the companies' activities mesh with other public policies that encourage the construction and consumption of housing; b) the appropriate safety-and-soundness regulatory structure; c) the systemic risks that may flow from the size of the companies; d) the effect of the companies activities on allocative efficiency; and e) the consequences of the two companies for efficient market structures.

\section{Encouragements for Housing and Macroeconomic Efficiency}

U.S. public policy, at all levels of government, encourages the construction and consumption of housing. The largest incentives pertain to income tax advantages: the exclusion of the implicit income from housing by owner-occupiers, while allowing the deduction of mortgage interest and local real estate taxes. Additional tax encouragements include the exemption of much owner-occupied housing from capital gains taxation and accelerated depreciation on rental housing. Direct provision of rental (“public”) housing is another significant program. 
In terms of housing finance, some government programs operate directly, like the mortgage insurance provided by FHA and VA (which allows lower down payments) and the securitization of associated mortgages by Ginnie Mae. Other programs support housing indirectly: federal deposit insurance for depository institutions whose portfolios contain some residential mortgages, savings and loan charters with mandates to invest in residential mortgages, and the Federal Home Loan Bank System -- originally created by the federal government in 1932 as a "wholesale" bank that would make low-cost loans to S\&Ls. Federal sponsorship of Fannie Mae and Freddie Mac are another indirect form of support for housing finance and hence housing consumption.

The motives underlying these public policy actions toward housing are diverse. One motive is to assist the middle class with a major household expenditure. Another motive is to support revenues and employment in residential construction, sales, and complementary industries. Yet another motive is that homeownership can be viewed as a way of encouraging households to save (at least so long home values do not decline, or other offsetting reductions in saving or increases in borrowing don't offset the value of home equity). But for most economists, the strongest arguments for government support of housing involve either a form of in-kind redistributions of income toward lower-income households, or the claim that homeownership has positive externalities. For example, an owner is likely to care more about a residence and the surrounding neighborhood than is an absentee landlord, which can result in positive externalities including the external appearance of property, greater watchfulness leading to greater public safety, and support for local public goods. A modest but growing empirical literature provides some documentation for these positive externalities for neighborhoods and even positive effects on owner-occupier families themselves. (Green and White, 1997; DiPasquale and Glaeser, 1999; Aaronson, 2000; and the references therein).

If redistribution to those with lower income or the positive externalities from a higher rate of homeownership are the goals, then the logical policy would encourage low- and moderate-income 
households, who may be on the margin between renting and owning, to become first-time home buyers. Such programs might aim to reduce down payments, since the size of down payment can be a binding constraint for low-income households (Linneman and Wachter, 1989; Quercia, McCarthy and Wachter, 2003), or to reduce monthly payments. However, most housing programs are broadbased efforts that encourage more housing construction and consumption throughout the income and social spectrum. For example, the income tax benefits from home ownership operate as exemptions and deductions, which means that they tend to favor disproportionately higher-income households in higher marginal tax brackets (Rosen, 1979; Gervais, 2002).

Federal sponsorship of Fannie Mae and Freddie Mac is of this broad-based nature. In 2002, the conforming loan limit for Fannie Mae and Freddie Mac was $\$ 300,700$. In that same year, according to the Federal Housing Finance Board, the median price of a new home that was sold was $\$ 187,600$, and an 80 percent mortgage on that sale price would have been $\$ 150,080$. Thus, the conforming loan limits allow Fannie Mae and Freddie Mac to purchase residential mortgage loans that are far beyond the range that would encompass the low- or moderate-income, first-time buying household. Fannie Mae and Freddie Mac are required to meet percent-of-business housing goals established by HUD involving annual purchases of loans involving a) households with less than median incomes; b) underserved areas, such as low-income and high-minority census tracts; and c) very low-income households and low-income households living in low-income areas. Nevertheless, the bulk of the mortgage purchases by the two companies have not involved the groups that ought to be the target of homeownership-encouraging activities (U.S. Office of Management and Budget, 2004). While some research has found that Fannie Mae and Freddie Mac have recently increased the supply of mortgage credit available to low- and moderate-income households (Ambrose and Thibodeau, 2004), it does not appear that the companies' activities have appreciably affected the rate of homeownership in the United States (Feldman, 2002; Painter and Redfearn, 2002; Freeman, Galster and Malega, 2003). 
Such broad-based encouragements for housing imply that most beneficiaries would have bought anyway, and the marginal effects are largely to cause them to buy larger and betterappointed homes, on larger lots, and/or to buy second homes. In turn, this broad-based encouragement means that the United States has invested in an inefficiently large housing stock, although the empirical literature that attempts to measure the magnitudes of these broad social consequences is surprisingly small. In one recent study, Gervais (2002) finds that the taxation of the implicit rents on owner-occupied housing (accompanied by a compensating adjustment in tax rates) could cause general consumption levels to increase by almost 5 percent. Taylor (1998) finds that over-investment in housing persisted during 1975-1995 and estimates the over-investment in housing at over \$220 billion per year (or \$300 per month for each owner-occupied home) for the late 1990s - consistent with prior research by Mills (1987a, b).

These results can be summarized bluntly. The United States has too much housing (and not enough of other goods and services), and federal sponsorship of Fannie Mae and Freddie Mac exacerbates this problem. Moreover, Fannie Mae and Freddie Mac do not do an especially good job of focusing on the low- and moderate-income first-time buyer where the social argument for support of homeownership is strongest.

\section{Safety and Soundness}

The implicit guarantee of Fannie Mae's and Freddie Mac's obligations suggests that attention be paid to the companies' financial health. How could either enterprise become insolvent? One way is if the credit losses mushroomed on the mortgages they guaranteed or held outright. This would occur if homeowners could not repay their mortgages and the prices of housing fell below outstanding loan values. Another - and perhaps more likely -- way is if they failed to hedge their market risks adequately, and the value of their mortgage portfolios fell 
below the values of their outstanding debt obligations. This happened to Fannie Mae, as well as to thousands of savings and loans, in the early 1980s.

What is the magnitude of this contingent liability to the federal government? One way to answer this question is to consider how much the government potentially would have to pay to a third party guarantor who would have the same probabilistic-contingent obligation to make whole the holders of Fannie Mae or Freddie Mac debt and mortgage-backed securities in the event that one of them failed. Such estimates are approximated by the gross benefits accruing to Fannie Mae and Freddie Mac from the implied guarantee in terms of both of the companies' debt and their mortgage-backed securities. ${ }^{8}$ A "back-of-the-envelope" calculation of this can be constructed using year-end 2003 data on their outstanding debt and mortgage-backed securities, coupled with estimates of the interest rate advantages that the two companies enjoy (40 basis points on debt and 30 basis points on mortgage-backed securities) as a result of implied government support, values for portfolio and MBS growth $\left(4 \%{ }^{9}\right)$, a discount rate $(5.00$ percent, based on long-term Treasury bond yields), and a time horizon (25 years). These numbers suggest an estimated contingent liability borne by the federal government of approximately \$288 billion.

The implied federal guarantee of Fannie Mae’s and Freddie Mac's financial obligations create a "moral hazard" problem. Because of the implied guarantee, creditors do not monitor the firms' activities as closely as they otherwise would. As a consequence of this reduced monitoring, the managements of Fannie Mae and Freddie Mac can engage in activities that involve greater risk (with greater liability consequences for the government), since the companies' owners will benefit

\footnotetext{
${ }^{8}$ Recall that the gross benefits from the implied guarantee are simply the differential between the interest rates that the GSEs' creditors actually demand (given their belief that the federal government would be likely to bail them out) and what they would require if the two companies were wholly divorced from the federal government.

${ }^{9}$ Though the overall mortgage market has grown at an average annual rate of 8.5 percent over the past decade, this rate could not be sustained indefinitely, nor could the two GSEs' even faster growth. Instead, we have assumed a growth rate that would be roughly equal to the growth of nominal U.S. GDP. At the other extreme, if the two GSEs' portfolios and MBS were to be frozen at year-end 2003 levels, the contingent liability would be "merely" \$183 billion.
} 
from the "upside" outcomes while being buffered (because of the limited liability of corporate owners) from the full consequences of large "downside" outcomes.

Safety-and-soundness regulatory oversight is one way to deal with insufficient market monitoring and discipline. However, in the case of Fannie Mae and Freddie Mac, the case for such regulation must be more nuanced. The federal guarantee itself is implicit and based on expectations, rather than a legally binding obligation of the government. The presence of safetyand-soundness oversight likely reinforces such expectations, and it is thus unclear whether safetyand-soundness regulation for Fannie Mae and Freddie Mac actually reduces taxpayer exposure (Frame and White, 2004a; Greenspan, 2004).

The Office of Federal Housing Enterprise Oversight (OFHEO), within the Department of Housing and Urban Development (HUD), is the safety and soundness regulator for Fannie Mae and Freddie Mac. OFHEO is authorized to set risk-based capital standards, conduct examinations, and take enforcement actions if unsafe or unsound financial or management practices are identified. ${ }^{10}$ However, OFHEO has been criticized for a perceived lack of effectiveness, including the lengthy delays that the regulator experienced in issuing and finalizing its risk-based capital regulation for Fannie Mae and Freddie Mac (U.S. General Accounting Office, 1997). More recently, Treasury Secretary John Snow (2003) remarked that there is a "general recognition that the supervisory system for the housing GSEs neither has the tools, nor the stature, to effectively deal with the current size, complexity, and importance of these enterprises.” Most important, OFHEO currently lacks the power to place an insolvent GSE into receivership.

A number of legislative proposals were introduced in Congress during 2003 to enhance the safety and soundness regulation of Fannie Mae and Freddie Mac (Frame and White, 2004a).

\footnotetext{
${ }^{10}$ Prior to the creation of OFHEO in 1992, HUD maintained exclusive regulatory oversight responsibilities over Fannie Mae and (for 1989-1992) Freddie Mac. Prior to the passage of the Financial Institutions Reform, Recovery and Enforcement Act of 1989, Freddie Mac was the responsibility of the Federal Home Loan Bank Board.
} 
These proposals would move the safety-and-soundness regulator for Fannie Mae and Freddie Mac out of HUD (where the culture is more focused on housing) and into either the Treasury (where the culture is more focused on safety and soundness) or create a freestanding agency outside the executive branch. This relocated regulatory agency might also be given some additional powers. For example, it might have the ability to levy fees on Fannie Mae and Freddie Mac to fund itself, thus removing the agency from the vagaries of annual budgetary appropriations. It would have a stronger ability to set and revise the minimum capital requirements that the two companies must meet, as well as to regulate new programs or new activities. Finally, the new agency might have the power to appoint a receiver that could liquidate or otherwise dispose of either Fannie Mae’s or Freddie Mac's assets in the event that one of them became insolvent. At the time that this article was completed in fall 2004, no definitive legislative action had been taken.

\section{Systemic Risk}

In recent testimony before Congress, Federal Reserve Chairman Greenspan (2004) suggested that Fannie Mae and Freddie Mac may pose "systemic risks" to the U.S. economy. That is, if one of the companies became financially distressed, enough harm to the overall financial system could be caused such that a non-trivial reduction in general economic activity would result. ${ }^{11}$ Such concerns generally begin with the observations that these companies are large, highly leveraged, and focused on a particular asset class that they dominate. As noted above, as of yearend 2003, Fannie Mae and Freddie Mac were the second and third largest U.S. companies measured by assets. In terms of financial leverage, Fannie Mae and Freddie Mac operated with ratios of total capital to total assets of 3.4 percent and 3.9 percent, respectively, as of that same date.

\footnotetext{
11 The discussion below focuses on systemic risks emanating from either (or both) Fannie Mae or Freddie Mac. Fahey (2003) and U.S. Office of Federal Housing Enterprise Oversight (2003) suggest that because of their implicit government guarantees, the companies might also act as a source of strength to financial markets in the face of external shocks.
} 
(By contrast, FDIC-insured depository institutions maintained a ratio of total capital to total assets of 9.2 percent on December 31, 2003.) Finally, about 86 percent of the combined balance sheet of Fannie Mae and Freddie Mac constitutes mortgage-related assets. Almost 50 percent of all the credit risk and 20 percent of all market risk associated with U.S. residential mortgage assets are held by the two companies. The U.S. Office of Federal Housing Enterprise Oversight (2003) provides a detailed discussion of systemic risk as it may pertain to Fannie Mae and Freddie Mac.

Concerns about the systemic consequences of Fannie Mae and Freddie Mac have focused on the concentration of market risk within the two companies. Fannie Mae and Freddie Mac do hedge these risks in their portfolios in various ways, thereby distributing the market risk into the broader capital market. One way they do this is by issuing "callable debt," so that if interest rates fall and a surge of prepaying home mortgage occurs, Fannie and Freddie can refinance their existing debt as well. The companies also use derivative financial instruments, like interest-rate swaps, to reduce their exposure to interest rate risk. Fannie Mae and Freddie Mac rely heavily on "dynamic hedging," whereby they rebalance their portfolios in response to changing interest rates that influence expected prepayment behavior (U.S. Office of Federal Housing Enterprise Oversight, 2003; Jaffee, 2003).

A specific area of systemic concern has been the effect of portfolio rebalancing by Fannie Mae and Freddie Mac on fixed-income markets. For example, a decline in the general level of interest rates often leads to increased prepayment risk, which in turn reduces the duration of mortgage-related assets. Holders of these assets, if they would like to maintain the original duration of their portfolios, would then have to purchase other longer-term assets to add duration. Increased demand for these longer-term assets would increase the price of these assets, or equivalently reduce the interest rates on them further. Perli and Sack (2003) present statistical evidence that mortgagerelated hedging significantly influences the behavior of the 10-year swap rate, although their analysis is not focused on Fannie Mae and Freddie Mac specifically. 
The U.S. Office of Federal Housing Enterprise Oversight (2003) notes several conditions that make an economy vulnerable to financial sector shocks, including weak market discipline of institutions and poor public disclosure. "Market discipline” refers to the ability of investors and creditors to track the changing financial condition and risk of firms and securities, to price securities accordingly, and, through pricing, to influence the actions of management (Bliss and Flannery, 2001). Consistent with the presence of some market discipline of Fannie Mae and Freddie Mac, Seiler (2003) finds that the share prices and debt yields of these companies respond to new information about their respective financial risks.

Fannie Mae and Freddie Mac have taken steps to strengthen their public disclosure through a set of six voluntary initiatives announced in 2000: 1) to issue subordinated debt, 2) to meet certain liquidity standards, 3) to enhance credit-risk disclosures, 4) to enhance interest rate disclosures; 5) to obtain annual credit ratings, and 6) to self-implement and report their regulatory risk-based capital levels. (This sixth initiative was rendered obsolete in 2002 when OFHEO’s risk-based capital standard became effective.) Also, in 2002 both Fannie Mae and Freddie Mac agreed to register their common stock with the Securities and Exchange Commission, although at the time of this writing only Fannie Mae has followed through. These steps all seem headed in the right direction, although some improvements also seem possible (Frame and Wall, 2002; Jaffee, 2003). A more direct approach to reducing systemic risk associated with Fannie Mae and Freddie Mac would be to limit their debt issuance, thereby capping the size of their respective balance sheets (Greenspan, 2004).

Two other arguments about systemic risk related to Fannie Mae and Freddie Mac have been discussed. One is that the companies have seemingly large exposures to a small number of derivatives counterparties. Fannie Mae and Freddie Mac are significant end-users of interest rate derivatives, and together the notional amount of these instruments outstanding as of year-end 2001 was \$1.6 trillion for the two companies. Moreover, as of the same date, five counterparties 
accounted for about 59 percent of their over-the-counter derivatives. However, the notional amounts of derivatives often bear little direct relationship to the actual credit exposure; as a simple example, an option to borrow $\$ 100$ million at a certain fixed rate of interest six months from today has a notional value of $\$ 100$ million - although the price of the actual option is much lower. Moreover, counterparties in a derivatives trade are required to post collateral if their net exposure exceeds certain limits, with lower-rated counterparties posting proportionately more collateral. Indeed, U.S. Office of Housing Enterprise Oversight (2003) reports that as of year-end 2001, the net uncollateralized exposures were only \$110 million for Fannie Mae and \$69 million for Freddie Mac. In the event of counterparty default, however, there is "rollover risk" to the extent that Fannie Mae and Freddie Mac find it difficult or particularly expensive to replace their hedging positions (Jaffee, 2003). An introduction to derivatives and their uses and misuses in this journal can be found in Stulz (2004).

The other argument is that, under current regulations, federally insured depository institutions can make unlimited investments in the obligations of Fannie Mae and Freddie Mac. However, as illustrated in Frame and Wall (2002), although a large number of banks hold such obligations in amounts that exceed their net worth (just over 50 percent as of year-end 2000), most of these institutions are very small (over 95 percent as of year-end 2000). Further, in the event of financial distress at either Fannie Mae or Freddie Mac, the value losses incurred by mortgagebacked securities investors would likely be minimal, given that the securities are fully collateralized by mortgages with very low historic loss rates. Kulp (2004) assesses the exposure of FDIC-insured institutions to privatization of Fannie Mae and Freddie Mac and finds minimal impact, although that analysis does not consider the impact in the case of financial distress at either or both of the companies.

\section{Allocative Efficiency}


The benefits embedded in the federal charters of Fannie Mae and Freddie Mac act as a barrier to entry in the secondary conforming mortgage market (Goodman and Passmore, 1992; Hermalin and Jaffee, 1996). In that market, Fannie Mae and Freddie Mac can be characterized as duopolists. However, instead of raising prices, Fannie Mae and Freddie Mac cause mortgage interest rates to be below those that the private market would otherwise provide. For this reason, Carlton, Gross and Stillman (2002) conclude that the two companies do not raise antitrust concerns.

Nevertheless, an examination of market power in the context of a government subsidy should not offer comparisons with an unsubsidized market, but instead should ask whether the subsidy is completely passed through by competing firms to customers. Some theoretical research has examined various equilibrium outcomes arising from interactions between a perfectly competitive primary mortgage market and a less than perfectly competitive secondary mortgage market (for example, Gan and Riddiough, 2004; Passmore, Sparks and Ingpen, 2002; Heuson, Passmore and Sparks, 2001; Passmore and Sparks, 2000). Such studies examine issues related to mortgage guarantee pricing as well as the distribution of mortgage credit risk (by risk classification) between mortgage originators and Fannie Mae and Freddie Mac.

The empirical evidence suggests that Fannie Mae and Freddie Mac do retain some portion of their federal benefits and hence are not acting in a perfectly competitive manner. One piece of casual evidence is the extraordinary profitability of these two firms. For the years 1998-2002, for example, Fannie Mae earned an average return on equity of 25.4 percent while Freddie Mac earned an average of 24.2 percent. By contrast, the industry return on equity for all FDIC-insured commercial banks for the same five years was around 14 percent. $^{12}$ A second piece of evidence is

\footnotetext{
${ }^{12}$ For the 15 years 1988-2002, Fannie Mae averaged 27.5 percent, while Freddie Mac averaged 23.5 percent. An alternative profitability ratio, return on assets (ROA), is substantially lower for Fannie Mae and Freddie Mac than that for commercial banks. The primary reason for this is that Fannie and Freddie are far more leveraged. As an indicator of likely rents from less-than-completely-vigorous competition, return on equity is the superior measure.
} 
from studies of using Fannie Mae and Freddie Mac as conduits for a mortgage interest rate subsidy. Feldman (1998) reviews the various approaches, while U.S. Congressional Budget Office (2001, 2004) and Passmore (2003) offer more recent analyses. For example, the U.S. Congressional Budget Office (2004) estimated that in 2003 the two companies received gross benefits of \$19.6 billion accruing from their federal charters, of which they passed through $\$ 13.4$ billion to homebuyers through lower mortgage rates and retained $\$ 6.2$ billion for their shareholders. Using a simulation exercise, Passmore (2003) estimates the median after-tax present value of Fannie Mae’s and Freddie Mac’s net federal benefits at \$72 billion, accounting for 60 percent of the companies’ combined market capitalization. Outside analyses sponsored by Fannie Mae disputes various assumptions and research methods used in these studies (for example, Toevs, 2001; Greene 2004; Blinder, Flannery and Kamihachi, 2004).

Of course, if one believes that broad-brush public policies encourage too much housing investment and that the activities of Fannie Mae and Freddie Mac exacerbate this problem, then the exercise of market power by these firms will improve allocative efficiency in the economy.

\section{Institutions for Greater Market Efficiency}

As an historical matter, Fannie Mae and Freddie Mac have surely enhanced the liquidity of mortgage loans, improved the geographic diversification of mortgage credit risk, and nationally integrated mortgage markets. Further, the presence of Fannie Mae and Freddie Mac and their implied guarantees may well have been important for the innovation and development of mortgage securitization in the 1970s and 1980s. Nevertheless, most of these benefits can now be achieved as a result of geographic deregulation of banking, which has allowed large, nationwide mortgage originators to emerge. Mortgage securitization is now a well-established technology of finance that does not require the special status of Fannie Mae and Freddie Mac. So, do Fannie Mae and Freddie 
Mac still provide a necessary institutional underpinning for a more efficient mortgage market in the current economic environment?

Because of their special status, Fannie Mae and Freddie Mac can issue blanket credit-loss guarantees on an entire pool of loans as well as avoid the costs of having their securities rated by rating agencies or registered with the Securities and Exchange Commission. In contrast, privatelabel mortgage-backed securities often have a structure that involves creating different levels of seniority of debt, obtaining securities ratings from rating agencies like Moody's or Standard \& Poor's, and registering with the Securities and Exchange Commission - all of which involve transactions costs. Further, investors in the senior mortgage-backed securities follow the credit performance of the underlying loans, which results in monitoring costs. In this way, the presence of Fannie Mae and Freddie Mac (and their special halo) might eliminate significant transactions costs (Woodward, 2004). However, these transaction costs are actually shifted rather than eliminated: investors believe that they are shielded from credit risk not only by Fannie Mae and Freddie Mac, but also ultimately by taxpayers.

Another argument is that the new-era securitization process is an inherently more efficient way of providing mortgage finance and that the expansion of Fannie Mae and Freddie Mac (with their implicit federal guarantee) at the expense of depositories' holdings of residential mortgages (supported by the depositories' explicit federal deposit insurance) is evidence of this superior efficiency (Van Order 2000a,b; 2001). Three potential counterpoints come to mind here. First, securitization is a widely used technology of finance in the United States: it permeates our consumer credit markets (mortgages, credit cards, auto loans) and is used by both depository and non-depository financial institutions. Second, as discussed earlier, an important reason why depository institutions securitize mortgages with Fannie Mae and Freddie Mac rather than holding them in their portfolios is the differential treatment of these assets for purposes of required regulatory risk-based capital. Finally, it is marginal debt funding costs that matter, rather than 
average costs. While these are probably roughly equal for Fannie Mae and Freddie Mac (that is, they face a perfectly elastic supply of loanable funds), banks likely face a rising marginal cost curve as they tap into non-core deposits or borrow money from wholesale lenders (like the Federal Home Loan Banks) or the capital markets. Hence, the extent to which the dramatic changes in the structure of U.S. residential mortgage markets are efficiency-driven rather than regulation-driven remains unclear. ${ }^{13}$

Finally, there is no assurance that the current organizational structures for Fannie Mae and Freddie Mac are the most efficient. Since the Congress has issued only two charters of this particular kind, no competitive processes exist to reward more efficient firms and winnow less efficient firms. The market for corporate control also cannot operate effectively, since the two companies' large sizes and special status likely make them immune to a takeover by a firm or an investor group.

\section{What is to be done?}

\section{First-Best}

There seems no strong efficiency reason for preserving the existing structure of Fannie Mae and Freddie Mac. They mostly just add to an already excessive encouragement for housing in the United States, using an implied guarantee that (to the extent that it would be honored) creates a contingent liability for the U.S. government. Thus, a complete privatization of the two companies would be the first-best outcome. In this vision, the two companies would no longer enjoy any special privileges, but also would no longer be restricted to their current narrow slice

13 As a related matter, whenever either of the two firms has expanded slightly in "horizontal" (sub-prime lending) or "vertical" (providing underwriting software to mortgage originators) directions -- or even publicly contemplated such moves -- critics have complained that the two companies' ability to expand arises solely from the low-cost funding that they enjoy from the implicit guarantee and not because of any inherent efficiency advantage. 
of the financial world. The consequence of such a step for residential mortgage markets would be modest: Mortgage rates would probably rise by about 20-25 basis points (ceteris paribus). Because it appears that the United States already builds and consumes too much housing, this would be a move in the right direction. Instead of backing a broad subsidy to housing through Fannie Mae and Freddie Mac, the federal government ought to focus on assisting first-time home buyers with low and moderate incomes (Calomiris, 2001; White, 2003).

\section{Second-Best}

The complete privatization of Fannie Mae and Freddie Mac seems an unlikely outcome in the current political environment. Accordingly, second-best measures should be considered.

One useful step would be for government officials to state clearly, whenever the subject comes up, that the federal government does not guarantee the debt of Fannie Mae or Freddie Mac and will not bail them (or their creditors) out. No presidential administration has explicitly made such a statement. More typical are carefully crafted comments that reiterate that the federal government is not required to bail out Fannie Mae or Freddie Mac, but fall short of flatly stating that the government will not do so (for example, Mankiw, 2004). One step toward separating the federal government from Fannie Mae and Freddie Mac has recently occurred. Five of the 18 board members of each company were historically appointed by the president; but in 2004, the Bush administration announced that it would cease appointing such members.

Second, the enterprises should be forced to focus more on the lower end of the housing market. The loan limit for a conforming mortgage might be frozen at its current level of $\$ 333,700$ for some years. HUD might strengthen the affordable housing goals that it sets for Fannie Mae and Freddie Mac. Indeed, as of the fall 2004 HUD is fielding comments on proposed revisions to these goals that would result in a marked increase in targeted lending. 
Third, the safety-and-soundness regime should be strengthened so that it is more comparable to that of the federal banking agencies. This step should include giving OFHEO or its successor: 1) responsibility for the approval of new programs and other activities; 2) the discretion to set both minimum and risk-based capital requirements; and 3) receivership authority. While the presence of a safety-and-soundness regulatory regime likely reinforces the market perception of an implied guarantee, stronger oversight should serve to reduce taxpayer exposure.

The policy issues raised by Fannie Mae and Freddie Mac are complex and increasingly important as these institutions grow and become a more pervasive influence on the financial sector. Although the first-best path of privatization may well be politically unrealistic, we believe that some constructive second-best measures deserve serious consideration. 


\section{Acknowledgements}

The views expressed in this paper do not necessarily reflect those of the Federal Reserve Bank of Atlanta, the Federal Reserve System, or their staffs. During 1986-1989, White was a board member of the Federal Home Loan Bank Board, with responsibilities that included being a board member of Freddie Mac. The authors thank the following for helpful comments: Mark Flannery, Michael Fratantoni, Edward Golding, Richard Green, James Hines, Dwight Jaffee, Wayne Passmore, Alex Pollock, Andrei Shleifer, Robin Seiler, Timothy Taylor, and Larry Wall. 


\section{References}

Aaronson, Daniel. 2000. A note on the benefits of homeownership. Journal of Urban Economics 47: 356-369.

Ambrose, Brent W., Michael LaCour-Little, and Anthony B. Sanders. Forthcoming. The effect of conforming loan status on mortgage yield spreads: A loan level analysis. Journal of Real Estate Economics.

Ambrose, Brent W. and Thomas G. Thibodeau. 2004. Have the GSE affordable housing goals increased the supply of mortgage credit? Regional Science and Urban Economics 34: 263-273.

Ambrose, Brent W. and Arthur Warga. 1996. Implications of privatization: the costs to Fannie Mae and Freddie Mac. In U.S. Department of Housing and Urban Development, Studies on Privatizing Fannie Mae and Freddie Mac. Washington, D.C.: HUD: 169-204.

Ambrose, Brent, and Arthur Warga. 2002. Measuring potential GSE funding advantages. Journal of Real Estate Finance and Economics 25(2/3): 129-150.

Blinder, Alan S., Mark J. Flannery, and James D. Kamihachi. 2004. The value of housing-related government sponsored enterprises: A review of a preliminary draft paper by Wayne Passmore. Fannie Mae Papers III(2). Available at: http://www.fanniemae.com/commentary/pdf/fmpv3i2.pdf.

Bliss, Robert R. and Mark J. Flannery. 2001. Market discipline in the governance of U.S. bank holding companies: Monitoring versus influencing. In Frederick S. Mishkin, ed., Bank Supervision: What Works and What Doesn't. Chicago: University of Chicago Press: 107-143.

Calomiris, Charles W. 2001. An economist's case for GSE reform. In Serving Two Masters yet out of Control: Fannie Mae and Freddie Mac, edited by Peter J. Wallison. Washington, D.C.: AEI Press.

Carlton, Dennis W., David B. Gross, and Robert S. Stillman. 2001. The competitive effects of Fannie Mae. Fannie Mae Papers, I(1). Available at: http://www.fanniemae.com/global/pdf/commentary/fmpv1i1.pdf.

Carnell, Richard S. 2004. Improving the regulation of Fannie Mae, Freddie Mac, and the Federal Home Loan Banks. Statement before the Committee on Banking, Housing, and Urban Affairs, U.S. Senate, February 10; available at: http://banking.senate.gov/_files/carnell.pdf.

DiPasquale, Denise and Edward L. Glaeser. 2002. Incentives and social capital: Are homeowners better citizens? Journal of Urban Economics 45: 354-384. 
Fabozzi, Frank J. 2001. The Handbook of Mortgage-Backed Securities. New York: McGrawHill.

Fahey, Noel. 2003. Systemic risk: A Fannie Mae perspective. Fannie Mae Papers II(2). Available at: http://www.fanniemae.com/commentary/pdf/fmpv2i2.pdf.

Fannie Mae, 1996. Fannie Mae review of the Hermalin-Jaffee paper. In Studies on Privatizing Fannie Mae and Freddie Mac. Washington, D.C.: HUD: 314-332.

Feldman, Ron. 1998. Estimating and managing the federal subsidy of Fannie Mae and Freddie Mac: Is either task possible? Journal of Public Budgeting, Accounting, and Financial Management 11 (Spring): 81-116.

Feldman, Ronald. 2002. Mortgage rates, homeownership rates, and government-sponsored enterprises. Federal Reserve Bank of Minneapolis The Region 16(1): 4-24.

Frame, W. Scott and Larry Wall. 2002. Fannie Mae's and Freddie Mac's voluntary initiatives: Lessons from banking. Federal Reserve Bank of Atlanta Economic Review 87 (first quarter): 4559.

Frame, W. Scott and Lawrence J. White. 2004a. Regulating housing GSEs: Thoughts on institutional structure and design. Federal Reserve Bank of Atlanta Economic Review 89 (second quarter): 87-102.

Frame, W. Scott and Lawrence J. White. 2004b. Increased Competition and Risk-Taking Incentives at Fannie Mae and Freddie Mac. Federal Reserve Bank of Atlanta working paper 2004-4.

Freeman, Lance, George Galster, and Ron Malega. 2003. The impact of secondary mortgage market and GSE purchases on underserved neighborhood housing markets: A Cleveland case study. Report to the U.S. Department of Housing and Urban Affairs. January, mimeo.

Gan, Jie and Timothy J. Riddiough. 2004. Pricing (and then papering over) the veil of ignorance: GSE monopoly and informational advantage in the market for residential mortgages. Mimeo, University of Wisconsin-Madison.

Gervais, Martin. 2002. Housing taxation and capital accumulation. Journal of Monetary Economics 49: 1461-1489.

Gonzalez-Rivera, Gloria. 2001. Linkages between secondary and primary markets for mortgages: The role of retained portfolio investments of the government-sponsored enterprises. Journal of Fixed Income 11(1): 29-36. 
Goodman, John L. and S. Wayne Passmore. 1992. Market power and the pricing or mortgage securitization. Federal Reserve Board's Finance and Economics Discussion Series, Number 187.

Green, Richard K. and Michelle J. White. 1997. Measuring the benefits of homeowning: Effects on children. Journal of Urban Economics 41(May): 441-461.

Greene, William. 2004. Commentary on "The GSE implicit subsidy and the value of government ambiguity”. Available at: http://www.fanniemae.com/commentary/pdf/021804.pdf.

Greenspan, Alan, 2004. Testimony before the Committee on Housing and Urban Affairs, U.S. Senate (February 24). Available at: http://www.federalreserve.gov/boarddocs/testimony/2004/20040224/default.htm.

Hermalin, Benjamin, and Dwight Jaffee. 1996. The privatization of Fannie Mae and Freddie Mac: Implications for mortgage industry structure. In Studies on Privatizing Fannie Mae and Freddie Mac. Washington, D.C.: HUD: 225-302.

Heuson, Andrea, Wayne Passmore and Roger Sparks. 2001. Credit scoring and mortgage securitization: Implications for mortgage rates and credit availability. Journal of Real Estate Finance and Economics 23(3): 337-363.

Inside Mortgage Finance. 2003. The 2003 Mortgage Market Statistical Annual, Volume II: The Secondary Mortgage Market. Bethesda, MD: Inside Mortgage Finance Publications, Inc.

Jaffee, Dwight. 2003. The interest rate risk of Fannie Mae and Freddie Mac. Journal of Financial Services Research, 24(1): 5-29.

Kane, Edward J. and Chester Foster. 1986. Valuing conjectural government guarantees of FNMA liabilities. In Proceedings: Conference on Bank Structure and Competition. Chicago: Federal Reserve Bank of Chicago.

Kulp, Charles. 2004. Assessing the banking industry's exposure to an implied government guarantee of GSEs (March 1). Available at: http://www.fdic.gov/bank/analytical/fyi/2004/030104fyi.html.

Linneman, Peter and Susan M. Wachter. 1989. The impact of borrowing constraints on home ownership. AREUEA Journal 17 (4): 389-402.

Mankiw, N. Gregory. 2004. Keeping Fannie and Freddie safe. Financial Times, February 24, p. 15.

McKenzie, Joseph. 2002. A reconsideration of the jumbo/non-jumbo mortgage rate differential. Journal of Real Estate Finance and Economics. 25(2/3): 197-213. 
Mills, Edwin S. 1987a. Has the United States overinvested in housing? AREUEA Journal 15 (Spring): 601-616.

Mills, Edwin S. 1987b. Dividing up the investment pie: Have we overinvested in housing? Federal Reserve Bank of Philadelphia Business Review (March/April): 13-23.

Naranjo, Andy and Alden Toevs. 2002. The effects of purchases of mortgages and securitization by government sponsored enterprises on mortgage yield spreads and volatility. Journal of Real Estate Finance and Economics. 25 (September-December): 173-195

Nothaft, Frank E., James E. Pearce, and Stevan Stevanovic. 2002. Debt spreads between GSEs and other corporations. Journal of Real Estate Finance and Economics 25 (SeptemberDecember): 151:172.

Painter, Gary and Christian L. Redfearn. 2002. The role of interest rates in influencing long-run homeownership rates. Journal of Real Estate Finance and Economics 25 (SeptemberDecember): 243-267.

Passmore, Wayne. 2003. The GSE implicit subsidy and the value of government ambiguity. Federal Reserve Board Finance and Economics Discussion Series Number 2003-64. Available at: http://www.federalreserve.gov/pubs/feds/2003/200364/200364pap.pdf.

Passmore, Wayne and Roger Sparks. 2000. Automated Underwriting and the Profitability of Mortgage Securitization. Journal of Real Estate Economics 25 (September-December): 285-305.

Passmore, Wayne, Roger Sparks, and Jamie Ingpen, 2002. GSEs, mortgage rates, and the longrun effects of securitization. Journal of Real Estate Finance and Economics 25 (SeptemberDecember): 215-242.

Peek, Joe and James A. Wilcox. 2003. Secondary Mortgage markets, GSEs, and the Changing Cyclicality of Mortgage Flows. Mimeo.

Perli, Roberto and Brian Sack. 2003. "Does Mortgage Hedging Amplify Movements in LongTerm Interest Rates?” Journal of Fixed Income 13(3): 7-17.

Quercia, Roberto G., George W. McCarthy, and Susan Wachter. 2003. The impacts of affordable lending efforts on homeownership rates. Journal of Housing Economics 12 (March): 29-59.

Rosen, Harvey S. 1979. Housing decisions and the U.S. income tax: An econometric analysis. Journal of Public Economics 11 (February): 1-23.

Seiler, Robert S. 2003. Market discipline of Fannie Mae and Freddie Mac: How do share prices and debt yield spreads respond to new information? Office of Federal Housing Enterprise Oversight Working Paper 03-4. 
Snow, John. 2003. Testimony before the Committee on Financial Services, U.S. House of Representatives. (September 10). Available at: http://www.treas.gov/press/releases/js716.htm.

Stulz, Rene M. 2004. Should we fear derivatives? Journal of Economic Perspectives, forthcoming.

Taylor, Lori L. 1998. Does the United States still overinvest in housing? Federal Reserve Bank of Dallas Economic Review (Second Quarter): 10-18.

Toevs, Alden L. 2001. A Critique of the CBO's Sponsorship Benefit Analysis. Available at: http://www.fanniemae.com/global/pdf/media/issues/010501fmcg.pdf.

U.S. Congressional Budget Office. 1996. Assessing the Public Costs and Benefits of Fannie Mae and Freddie Mac. Washington, D.C.: CBO.

U.S. Congressional Budget Office. 2001. Federal Subsidies and the Housing GSEs. Washington, D.C.: CBO.

U.S. Congressional Budget Office. 2004. Updated Estimates of the Subsidies to the Housing GSEs. April 8. Washington, D.C.: CBO.

U.S. Department of the Treasury. 1996. Government Sponsorship of the Federal National Mortgage Association and the Federal Home Loan Mortgage Corporation. Washington, D.C.: Treasury.

U.S. Federal Deposit Insurance Corporation. 1997. History of the Eighties - Lessons for the Future. Vol. I. Washington, D.C.: FDIC.

U.S. General Accounting Office. 1990. Government-Sponsored Enterprises: The Government's Exposure to Risks. Washington, D.C.: GAO.

U.S. General Accounting Office. 1996. Housing Enterprises: Potential Impacts of Severing Government Sponsorship (GAO/GGDS 96-120). Washington, D.C.: GAO.

U.S. General Accounting Office. 1997. Federal Housing Enterprises: OFHEO Faces Challenges in Implementing a Comprehensive Oversight Program. Washington, D.C.: GAO.

U.S. Office of Federal Housing Enterprise Oversight. 2003. Systemic Risk: Fannie Mae, Freddie Mac and the Role of OFHEO. Washington, D.C.: OFHEO.

U.S. Office of Management and Budget. 2004. Budget of the United States Government, Fiscal Year 2004: Analytical Perspectives. Washington, D.C.: GPO. 
Van Order, Robert. 2000a. A microeconomic analysis of Fannie Mae and Freddie Mac. Regulation 23(2): 27-33.

Van Order, Robert. 2000b. The U.S. mortgage market: a model of dueling charters. Journal of Housing Research 11(2): 233-255.

Van Order, Robert. 2001. The economics of Fannie Mae and Freddie Mac, in Peter J. Wallison, ed., Serving Two Masters, Yet Out of Control: Fannie Mae and Freddie Mac. Washington, D.C.: AEI Press: 41-54.

White, Lawrence J. 2003. Focusing on Fannie and Freddie: The dilemmas of reforming housing finance. Journal of Financial Services Research, 23 (February): 43-58.

Woodward, Susan E. 2004. Rechartering Freddie and Fannie: The policy issues. Mimeo, Sand Hill Econometrics, Menlo Park, CA. 
Table 1

Fannie Mae and Freddie Mac Assets and Mortgage-backed Securities, and the Mortgage Market (in billions of dollars, includes single- and multi-family mortgages)

\begin{tabular}{|c|c|c|c|c|c|c|c|}
\hline \multirow[b]{2}{*}{ Year } & \multicolumn{3}{|l|}{ Fannie Mae } & \multicolumn{3}{|l|}{ Freddie Mac } & \multirow[b]{2}{*}{$\begin{array}{l}\text { Total nonfarm, } \\
\text { residential } \\
\text { mortgages }\end{array}$} \\
\hline & Total assets & $\begin{array}{l}\text { Retained } \\
\text { mortgage } \\
\text { portfolio }^{\mathrm{a}}\end{array}$ & $\begin{array}{l}\text { Mortgage- } \\
\text { backed } \\
\text { securities } \\
\text { outstanding }\end{array}$ & Total assets & $\begin{array}{l}\text { Retained } \\
\text { mortgage } \\
\text { portfolio }^{a}\end{array}$ & $\begin{array}{l}\text { Mortgage- } \\
\text { backed } \\
\text { securities } \\
\text { outstanding }\end{array}$ & \\
\hline 1980 & $\$ 57.9$ & $\$ 55.6$ & $\$ 0.0$ & $\$ 5.5$ & $\$ 5.0$ & $\$ 17.0$ & $\$ 1,105$ \\
\hline 1985 & 99.1 & 94.1 & 54.6 & 16.6 & 13.5 & 99.9 & 1,730 \\
\hline 1990 & 133.1 & 114.1 & 288.1 & 40.6 & 21.5 & 316.4 & 2,907 \\
\hline 1995 & 316.6 & 252.9 & 513.2 & 137.2 & 107.7 & 459.0 & 3,745 \\
\hline 2000 & 675.2 & 607.7 & 706.7 & 459.3 & 385.5 & 576.1 & 5,543 \\
\hline 2001 & 799.9 & 706.8 & 859.0 & 641.1 & 503.8 & 653.1 & 6,110 \\
\hline 2002 & 887.5 & 801.1 & $1,029.5$ & 752.2 & 589.9 & 749.3 & 6,842 \\
\hline 2003 & $1,009.6$ & 901.9 & $1,300.2$ & 803.4 & 660.4 & 768.9 & 7,715 \\
\hline
\end{tabular}

a Includes repurchased mortgage-backed securities.

${ }^{\mathrm{b}}$ Excludes mortgage-backed securities that are held in portfolio

Sources: OFHEO, Federal Reserve, Freddie Mac 
Table 2

Holders of Single-Family Residential Mortgages (Credit Exposures), 1970-2000

\begin{tabular}{|l|l|l|l|l|l|l|l|}
\hline & $\mathbf{1 9 7 0}$ & $\mathbf{1 9 7 5}$ & $\mathbf{1 9 8 0}$ & $\mathbf{1 9 8 5}$ & $\mathbf{1 9 9 0}$ & $\mathbf{1 9 9 5}$ & $\mathbf{2 0 0 0}$ \\
\hline & & & & & & & \\
\hline Total (\$ Billion) & $\mathbf{2 9 7 . 8}$ & $\mathbf{4 8 2 . 0}$ & $\mathbf{9 6 6 . 2}$ & $\mathbf{1 5 2 3 . 5}$ & $\mathbf{2 6 1 9 . 9}$ & $\mathbf{3 4 7 8 . 2}$ & $\mathbf{5 2 0 5 . 4}$ \\
\hline & & & & & & & \\
\hline Banks \& Thrifts & 210.0 & 351.8 & 647.4 & 765.5 & 1030.5 & 1128.9 & 1559.9 \\
\hline Commercial Banks & 42.9 & 77.8 & 160.1 & 211.2 & 430.3 & 646.5 & 965.6 \\
\hline Thrifts & 167.1 & 274.0 & 487.3 & 554.3 & 600.2 & 482.4 & 594.2 \\
\hline & & & & & & & \\
\hline Fannie Mae \& Freddie Mac & 15.2 & 31.8 & 69.1 & 257.3 & 713.1 & 1285.5 & 2020.0 \\
\hline Fannie Mae & 15.2 & 25.8 & 51.8 & 145.9 & 385.5 & 733.4 & 1160.5 \\
\hline Freddie Mac & 0.0 & 5.9 & 17.3 & 111.4 & 327.6 & 552.1 & 859.5 \\
\hline & & & & & & & \\
\hline Ginnie Mae & 3.3 & 22.3 & 92.3 & 206.7 & 391.5 & 461.4 & 592.6 \\
\hline & & & & & & & \\
\hline All Others (Residual) & 69.4 & 76.2 & 157.5 & 294.0 & 484.8 & 602.4 & 1032.9 \\
\hline & & & & & & & \\
\hline \% Distribution & & & & & & & \\
\hline & & & & & & & \\
\hline Banks \& Thrifts & $\mathbf{7 0 . 5 \%}$ & $\mathbf{7 3 . 0 \%}$ & $\mathbf{6 7 . 0 \%}$ & $\mathbf{5 0 . 2 \%}$ & $\mathbf{3 9 . 3 \%}$ & $\mathbf{3 2 . 5 \%}$ & $\mathbf{3 0 . 0 \%}$ \\
\hline Commercial Banks & $14.4 \%$ & $16.1 \%$ & $16.6 \%$ & $13.9 \%$ & $16.4 \%$ & $18.6 \%$ & $18.6 \%$ \\
\hline Thrifts & $56.1 \%$ & $56.8 \%$ & $50.4 \%$ & $36.4 \%$ & $22.9 \%$ & $13.9 \%$ & $11.4 \%$ \\
\hline & & & & & & & \\
\hline Fannie Mae \& Freddie Mac & $\mathbf{5 . 1 \%}$ & $\mathbf{6 . 6 \%}$ & $\mathbf{7 . 2 \%}$ & $\mathbf{1 6 . 9 \%}$ & $\mathbf{2 7 . 2 \%}$ & $\mathbf{3 7 . 0 \%}$ & $\mathbf{3 8 . 8 \%}$ \\
\hline Fannie Mae & $5.1 \%$ & $5.4 \%$ & $5.4 \%$ & $9.6 \%$ & $14.7 \%$ & $21.1 \%$ & $22.3 \%$ \\
\hline Freddie Mac & $0.0 \%$ & $1.2 \%$ & $1.8 \%$ & $7.3 \%$ & $12.5 \%$ & $15.9 \%$ & $16.5 \%$ \\
\hline & & & & & & & \\
\hline Ginnie Mae & $\mathbf{1 . 1 \%}$ & $\mathbf{4 . 6 \%}$ & $\mathbf{9 . 6 \%}$ & $\mathbf{1 3 . 6 \%}$ & $\mathbf{1 4 . 9 \%}$ & $\mathbf{1 3 . 3 \%}$ & $\mathbf{1 1 . 4 \%}$ \\
\hline & & & & & & & \\
\hline
\end{tabular}


Note: This table indicates who owns single-family residential mortgages (and excludes any holdings of mortgage-backed securities); in essence, it indicates who bears the credit risks on mortgages. Source: Federal Reserve, Fannie Mae 